\title{
REVIEW \\ PROF-962
}

\section{SERUM TUMOR MARKERS}

\author{
DR FAISAL BILAL LODHI, FCPS \\ Assistant Professor of Surgery \\ Punjab Medical College, FAisalabad \\ DR MUHAMMAD ALI, FCPS \\ Senior Registrar (Surgery) \\ Allied Hospital, Faisalabad \\ DR IFTIKHAR, FCPS
}

\author{
Senior Registrar (Surgery) \\ Allied Hospital, Faisalabad \\ Dr Riaz Hussain, FRCS \\ Professor of Surgery \\ Punjab Medical College, Faisalabad.
}

\begin{abstract}
With the advent of new generations of chemotherapeutic agents and advances in radiation therapy in the management of malignancies, an understanding of tumor markers is becoming increasingly important. These soluble molecules in the blood are usually glycoproteins detected by monoclonal antibodies. Each tumor marker has a variable profile of usefulness for screening, determining diagnosis and prognosis, assessing response to therapy, and monitoring for cancer recurrence. Monoclonal antibodies are used to detect serum antigens associated with specific malignancies. These tumor markers are most useful for monitoring response to therapy and detecting early relapse. With the exception of Prostate-Specific Antigen (PSA), tumor markers do not have sufficient sensitivity or specificity for use in screening. Cancer Antigen (CA) 27.29 most frequently is used to follow response to therapy in patients with metastatic breast cancer. Carcinoembryonic antigen is used to detect relapse of colorectal cancer, and CA 19-9 may be helpful in establishing the nature of pancreatic masses. CA 125 is useful for evaluating pelvic masses in postmenopausal women, monitoring response to therapy in women with ovarian cancer, and detecting recurrence of this malignancy. Alpha-fetoprotein (AFP), a marker for hepatocellular carcinoma, sometimes is used to screen highly selected populations and to assess hepatic masses in patients at particular risk for developing hepatic malignancy. Testing for the beta subunit of human chorionic gonadotropin ( $b-h C G)$ is an integral part of the diagnosis and management of gestational trophoblastic disease. Combined AFP and b-hCG testing is an essential adjunct in the evaluation and treatment of nonseminomatous germ cell tumors, and in monitoring the response to therapy. AFP and b-hCG also may be useful in evaluating potential origins of poorly differentiated metastatic cancer. PSA is used to screen for prostate cancer, detect recurrence of the malignancy, and evaluate specific syndromes of adenocarcinoma of unknown primary. This review article describes the use of common tumor markers in primary care practice. Particular emphasis is given to when these tests should be ordered and to common factors that influence the interpretation of tumor marker levels.
\end{abstract}

Key Words: Tumor Markers, Serum Tumor Markers 


\section{INTRODUCTION}

Screening tests require high sensitivity to detect earlystage disease. These tests also must have sufficient specificity to protect patients with false-positive results from unwarranted diagnostic evaluations. To date, no tumor marker has demonstrated a survival benefit in randomized controlled trials of screening in the general population. Nevertheless, tumor markers can play a crucial role in detecting disease and assessing response to therapy in selected groups of patients. In monitoring patients for disease recurrence, tumor marker levels should be determined only when there is a potential for meaningful treatment.

Normalization of tumor marker values may indicate cure despite radiographic evidence of persistent disease. In this circumstance, the residual tumor is frequently nonviable. Conversely, tumor marker levels may rise after effective treatment (possibly related to cell lysis), but the increase may not portend treatment failure. However, a consistent increase in tumor marker levels, coupled with lack of clinical improvement, may indicate treatment failure. Residual elevation after definitive treatment usually indicates persistent disease. Following tumor marker response is particularly useful when other evidence of disease is not readily accessible.

\section{CANCER ANTIGEN 27.29}

Cancer antigen (CA) 27.29 is a monoclonal antibody to a glycoprotein (MUC1) that is present on the apical surface of normal epithelial cells. CA 27.29 is highly associated with breast cancer, although levels are elevated in several other malignancies (Table-1).1-14 CA 27.29 also can be found in patients with benign disorders of the breast, liver, and kidney, and in patients with ovarian cysts. However, CA 27.29 levels higher than 100 units per $\mathrm{mL}$ are rare in benign conditions ${ }^{1}$.

\begin{tabular}{|c|c|c|c|c|c|c|}
\hline $\begin{array}{l}\text { Tumour } \\
\text { marker }\end{array}$ & Normal value & $\begin{array}{l}\text { Primary } \\
\text { tumours }\end{array}$ & $\begin{array}{l}\text { Additional associated } \\
\text { malignancies }\end{array}$ & $\begin{array}{l}\text { Benign } \\
\text { conditions }\end{array}$ & $\begin{array}{l}\text { Level above } \\
\text { which benign } \\
\text { disease is } \\
\text { unlikely }\end{array}$ & Sensitivity \\
\hline $\begin{array}{l}\text { CA } \\
27.29^{1,2}\end{array}$ & $<38$ units per $\mathrm{ml}$ & Breast cancer & $\begin{array}{l}\text { Colon, gastric, hepatic, } \\
\text { lung, pancreatic, ovarian } \\
\text { and prostate cancers }\end{array}$ & $\begin{array}{l}\text { Breast, liver and } \\
\text { kidney disorders, } \\
\text { ovarian cyst }\end{array}$ & $>100$ units per $\mathrm{ml}$ & $\begin{array}{l}\text { Elevated in about } \\
33 \% \text { of early } \\
\text { stage breast } \\
\text { cancers and } \\
\text { about } 67 \% \text { of late } \\
\text { stage breast } \\
\text { cancers }\end{array}$ \\
\hline $\mathrm{CEA}^{3,4}$ & $\begin{array}{l}>2.5 \mathrm{ng} \text { per } \\
<\mathrm{ng} \text { per ml in } \\
\text { smokers }\end{array}$ & $\begin{array}{l}\text { Colorectal } \\
\text { cancer }\end{array}$ & $\begin{array}{l}\text { Breast, lung, gastric, } \\
\text { pancreatic, bladder, } \\
\text { medullary thyroid, head } \\
\text { and neck, cervical and } \\
\text { hepatic cancers, } \\
\text { lymphoma, melanoma }\end{array}$ & $\begin{array}{l}\text { Cigarette, smoking, } \\
\text { peptic ulcer } \\
\text { disease, } \\
\text { inflammatory bowel } \\
\text { disease, } \\
\text { pancreatitis, } \\
\text { hypothyroidism, } \\
\text { cirrhosis, biliary } \\
\text { obstruction }\end{array}$ & $>10 \mathrm{ng}$ per $\mathrm{ml}$ & $\begin{array}{l}\text { Elevated in less } \\
\text { than } 25 \% \text { of early } \\
\text { stage colon } \\
\text { cancers } 75 \% \text { of } \\
\text { late stage colon } \\
\text { cancers }\end{array}$ \\
\hline
\end{tabular}




\begin{tabular}{|c|c|c|c|c|c|c|}
\hline CA $19-9^{5}$ & $<37$ units per $\mathrm{ml}$ & $\begin{array}{l}\text { Pancreatic } \\
\text { cancer, biliary } \\
\text { tract cancers }\end{array}$ & $\begin{array}{l}\text { Colon, esophageal and } \\
\text { hepatic cancers }\end{array}$ & $\begin{array}{l}\text { Pancreatitis, biliary } \\
\text { disease, cirrhosis }\end{array}$ & $\begin{array}{l}>1,000 \text { units per } \\
\mathrm{ml}\end{array}$ & $\begin{array}{l}\text { Elevated in } 80 \% \\
\text { to } 90 \% \text { of } \\
\text { pancreatic } \\
\text { cancers and } 60 \% \\
\text { to } 70 \% \text { of biliary } \\
\text { tract cancers* }\end{array}$ \\
\hline $\mathrm{AFP}^{6}$ & $<5.4 \mathrm{ng}$ per $\mathrm{ml}$ & $\begin{array}{l}\text { Hepatocellular } \\
\text { carcinoma, } \\
\text { nonseminomat } \\
\text { ous germ cell } \\
\text { tumours }\end{array}$ & $\begin{array}{l}\text { Gastric, biliary and } \\
\text { pancreatic cancers }\end{array}$ & $\begin{array}{l}\text { Cirrhosis, viral } \\
\text { hepatitis, } \\
\text { pregnancy }\end{array}$ & $>500 \mathrm{ng}$ per $\mathrm{ml}$ & $\begin{array}{l}\text { Elevated in } 80 \% \text { o } \\
\text { hepatocellular } \\
\text { carcinomas } \\
\text { nonseminomatou } \\
\text { s germ cell } \\
\text { tumours see b-c } \\
\text { HG below }\end{array}$ \\
\hline b-h $\mathrm{CG}^{7,8}$ & $<5 \mathrm{mlU}$ per $\mathrm{ml}$ & $\begin{array}{l}\text { nonseminomat } \\
\text { ous germ cell } \\
\text { tumours, } \\
\text { gestational } \\
\text { trophoblastic } \\
\text { disease }\end{array}$ & $\begin{array}{l}\text { Rarely, gastrointestinal } \\
\text { cancers }\end{array}$ & $\begin{array}{l}\text { Hypogonadal } \\
\text { states, marijuana } \\
\text { use }\end{array}$ & $>30 \mathrm{mlU}$ per $\mathrm{ml}^{7}$ & $\begin{array}{l}\text { AFP or b-h CG } \\
\text { elevated in } 85 \% \\
\text { of } \\
\text { nonseminomatou } \\
\text { s germ cell } \\
\text { tumours, elevated } \\
\text { in only } 20 \% \text { of } \\
\text { early stage } \\
\text { nonseminomatou } \\
\text { s germ cell } \\
\text { tumours }\end{array}$ \\
\hline${ }_{11} A A 125^{9-}$ & $<35$ units per $\mathrm{ml}$ & Ovarian cancer & $\begin{array}{l}\text { Endometrial, fallopian } \\
\text { tube, breast, lung, } \\
\text { esophageal, gastric, } \\
\text { hepatic, and pancreatic } \\
\text { cancers }\end{array}$ & $\begin{array}{l}\text { Menstruation, } \\
\text { pregnancy, fibroids, } \\
\text { ovarian cyst, pelvic } \\
\text { inflammation, } \\
\text { cirrhosis, ascites, } \\
\text { pleural and } \\
\text { pericardial } \\
\text { effusions, } \\
\text { endometriosis }\end{array}$ & $\begin{array}{l}>200 \text { units per } \\
\mathrm{ml}^{11}\end{array}$ & $\begin{array}{l}\text { Elevated in about } \\
85 \% \text { of ovarian } \\
\text { cancers; elevated } \\
\text { in only } 50 \% \text { of } \\
\text { early stage } \\
\text { ovarian cancers }\end{array}$ \\
\hline $\mathrm{PSA}^{12-14}$ & $\begin{array}{l}<4 \text { ng per ml for } \\
\text { screening } \\
\text { undetectable level } \\
\text { after radical } \\
\text { prostatectomy }\end{array}$ & $\begin{array}{l}\text { Prostate } \\
\text { cancer }\end{array}$ & None & $\begin{array}{l}\text { Prostatitis, benign } \\
\text { prostatic } \\
\text { hypertrophy, } \\
\text { prostatic trauma, } \\
\text { after ejaculation }\end{array}$ & $>10 \mathrm{ng}$ per $\mathrm{ml}^{12}$ & $\begin{array}{l}\text { Elevated in more } \\
\text { than } 75 \% \text { of organ } \\
\text { confined prostate } \\
\text { cancers }^{14}\end{array}$ \\
\hline \multicolumn{7}{|c|}{$\begin{array}{c}C A=\text { cancer antigen; } C E A=\text { Carcinoembryonic antigen; } A F P=\text { Alpha-fetoprotein; } \boldsymbol{b}-\boldsymbol{h} \text { CG }=\text { Beta subunt of human choroinic gonadotropin; } P S A= \\
\text { Prostate-specific antigen. * The greatest possible sensitivity is } 95 \% \text {, given that } 5 \% \text { of the population have Lewis-null blood type and are unable to } \\
\text { produce the antigen. }\end{array}$} \\
\hline
\end{tabular}

Because of superior sensitivity and specificity, CA 27.29 has supplanted CA 15-3 as the preferred tumor marker in breast cancer. The CA 27.29 level is elevated in approximately one third of women with early-stage breast cancer (stage I or II) and in two thirds of women with late-stage disease (stage III or IV). 2 CA 27.29 lacks predictive value in the earliest stages of breast cancer and thus has no role in screening for or diagnosing the malignancy.

Disagreement exists about the ability of CA 27.29 to detect asymptomatic recurrence after curative treatment. One trial1 in patients at high risk for recurrence of breast cancer (stage II or III) found that CA 27.29 was highly specific and sensitive in detecting preclinical metastasis. The average time from initial elevation of CA 27.29 to 
onset of symptoms was five months. Because CA 27.29 testing may lead to prompt imaging of probable sites of metastasis, it may be possible to decrease morbidity through earlier institution of therapy.

\section{Carcinoembryonic Antigen}

Carcinoembryonic antigen (CEA), an oncofetal glycoprotein, is expressed in normal mucosal cells and over expressed in adenocarcinoma, especially colorectal cancer (Table I).1-14 CEA elevations also occur with other malignancies. Non-neoplastic conditions associated with elevated CEA levels include cigarette smoking, peptic ulcer disease, inflammatory bowel disease, pancreatitis, hypothyroidism, biliary obstruction, and cirrhosis. Levels exceeding $10 \mathrm{ng}$ per $\mathrm{mL}$ are rarely due to benign disease ${ }^{3}$.

One trial found that monitoring of cancer antigen 27.29 levels in patients at high risk for recurrence of breast cancer (stage II or III) was associated with identification of relapse an average of five months before onset of symptoms

Fewer than 25 percent of patients with disease confined to the colon have an elevated CEA level. Sensitivity increases with advancing tumor stage: CEA values are elevated in approximately 50 percent of patients with tumor extension to lymph nodes and 75 percent of patients with distant metastasis ${ }^{4}$. The highest values (above $100 \mathrm{ng}$ per $\mathrm{mL}$ ) occur with metastasis, 15 although poorly differentiated tumors are less likely to produce $C E A^{4}$.

CEA is not useful in screening for colorectal cancer or in the diagnostic evaluation of an undefined illness. A CEA level should be ordered only after malignancy has been confirmed. CEA levels typically return to normal within four to six weeks after successful surgical resection ${ }^{3}$.

The major role for CEA levels is in following patients for relapse after intended curative treatment of colorectal cancer. When patients with a normal preoperative CEA level have cancer recurrence, CEA elevation is a sign in nearly one half of them ${ }^{4}$.
The American Society of Clinical Oncology recommends monitoring CEA levels every two to three months for at least two years in patients with stage II or III disease who are surgical candidates. ${ }^{16}$ When an abnormal level is found, the test should be repeated; if CEA elevation is confirmed, patients should undergo imaging of potential recurrence sites. Local recurrence or limited metastasis to liver or lung can be resected with curative intent. Clinical trials examined in one meta-analysis ${ }^{17}$ demonstrated a 9 percent (absolute value) improvement in survival after five years in patients who underwent CEA monitoring as part of post-treatment management.

\section{Cancer Antigen 19-9}

Elevated levels of CA 19-9, an intracellular adhesion molecule, occur primarily in patients with pancreatic and biliary tract cancers but also have been reported in patients with other malignancies (Table 1$)^{1-14}$. This tumor marker has a sensitivity and specificity of 80 to 90 percent for pancreatic cancer and a sensitivity of 60 to 70 percent for biliary tract cancer. Benign conditions such as cirrhosis, cholestasis, cholangitis, and pancreatitis also result in CA 19-9 elevations, although values are usually less than 1,000 units per $\mathrm{mL}^{5}$.

Patients with Lewis-null blood type do not produce CA 19-9. Thus, about 5 percent of persons are unable to produce this antigen 5 .

Use of CA 19-9 is limited. The antigen has no value in screening because its positive predictive value is less than 1 percent. 18 However, the positive predictive value of levels over 1,000 units per $\mathrm{mL}$ is 97 percent when CA 19-9 testing is used in clinical situations that are consistent with pancreatic cancer (e.g., jaundice associated with a pancreatic mass). Furthermore, CA 199 levels above 1,000 units per $\mathrm{mL}$ predict the presence of metastatic disease ${ }^{5}$.

\section{Alpha-Fetoprotein (AFP)}

Alpha-fetoprotein is the major protein of fetal serum but falls to an undetectable level after birth. The primary malignancies associated with AFP elevations are hepatocellular carcinoma and nonseminomatous germ 
cell tumors. Other gastrointestinal cancers occasionally cause elevations of AFP, but rarely to greater than 1,000 ng per $\mathrm{mL}^{6}$.

Patients with cirrhosis or viral hepatitis may have abnormal AFP values, although usually less than $500 \mathrm{ng}$ per $\mathrm{mL}$. Pregnancy also is associated with elevated AFP levels, particularly if the pregnancy is complicated by a spinal cord defect or other abnormality ${ }^{6}$.

AFP levels are abnormal in 80 percent of patients with hepatocellular carcinoma and exceed 1,000 ng per $\mathrm{mL}$ in 40 percent of patients with this cancer. ${ }^{6}$ Although randomized controlled trials have not shown mortality risk benefit, the use of AFP in hepatocellular carcinoma screening continues to be debated. Retrospective studies $^{19,20}$ in Asia showed improved survival with AFP screening, but the findings of this study have not been duplicated.

Some experts use annual AFP and ultrasound screening in patients with well-compensated nonalcohol-induced cirrhosis $^{20}$. In patients with a hepatic mass and risk factors for hepatocellular carcinoma, an AFP level above $500 \mathrm{ng}$ per $\mathrm{mL}$ is often used in lieu of biopsy to diagnose hepatocellular carcinoma ${ }^{6}$.

\section{Beta Subunit of Human Chorionic Gonadotropin}

The beta subunit of human chorionic gonadotropin (bhCG) normally is produced by the placenta. Elevated bhCG levels most commonly are associated with pregnancy, germ cell tumors, and gestational trophoblastic disease. False-positive levels occur in hypogonadal states and with marijuana use ${ }^{7}$.

Both AFP and b-hCG play crucial roles in the management of patients with nonseminomatous germ cell tumors. The AFP or b-hCG level is elevated in 85 percent of patients with these tumors (Table I) $)^{1-14}$, but in only 20 percent of patients with stage I disease ${ }^{8}$. Hence, these markers have no role in screening. Marked elevations of AFP or b-hCG are associated with very few disease states (Table II).
In patients with extragonadal disease or metastasis at the time of diagnosis, highly elevated AFP or b-hCG values can be used in place of biopsy to establish a diagnosis of non-seminomatous germ cell tumor. AFP values in excess of $10,000 \mathrm{ng}$ per $\mathrm{mL}$ or $\mathrm{b}$-hCG levels above $50,000 \mathrm{mIU}$ per $\mathrm{mL}$ at initial diagnosis portend a poor prognosis, with a five-year survival rate of 50 percent. Similarly staged patients with lower AFP and bhCG levels have a cure rate higher than 90 percent $^{21}$.

\begin{tabular}{|c|c|c|}
\hline \multicolumn{3}{|c|}{$\begin{array}{l}\text { Table-II. AFP and b-hCG levels in germ cell tumors and } \\
\text { gestational trophoblastic disease }\end{array}$} \\
\hline Tumour & $\begin{array}{l}\text { AFP } \\
\text { elevation }\end{array}$ & $\begin{array}{l}\text { b-hCG } \\
\text { elevation }\end{array}$ \\
\hline $\begin{array}{l}\text { Seminoma and } \\
\text { dysgerminoma }\end{array}$ & Nevers* & $\begin{array}{l}\text { Occasional, } \\
\text { minimal }\end{array}$ \\
\hline Embryonal cell carcinoma & Yes & Yes \\
\hline Choriocarcinoma & No & Yes \\
\hline Yolk sac tumors & Yes & No \\
\hline Teratoma & No & No \\
\hline $\begin{array}{l}\text { Gestational trophoblastic } \\
\text { disease**}\end{array}$ & No & Yes \\
\hline \multicolumn{3}{|c|}{$\begin{array}{c}\text { AFP = Alpha-fetoprotein, } b-h C G=\text { beta subunit of human } \\
\text { chorionic gonadotropin: * Any detectable AFP indicates the } \\
\text { presence of a nonseminomatous component, in this situation, } \\
\text { the malignancy should be treated as a nonseminomatous germ } \\
\text { cell tumor: }{ }^{* *} \text { Gestational trophoblastic disease is not a germ } \\
\text { cell tumor, rather, it is a rare gynecologic malignancy related to } \\
\text { pregnancy }\end{array}$} \\
\hline
\end{tabular}

Following AFP and b-hCG levels is imperative in monitoring response to treatment in patients who have nonseminomatous germ cell tumors. Patients with AFP and $b$-hCG levels that do not decline as expected after treatment have a significantly worse prognosis, and changes in therapy should be considered ${ }^{22}$. Because curative salvage therapy is possible, the tumor markers are followed every one to two months for one year after treatment, then quarterly for one year, and less frequently thereafter ${ }^{8}$. AFP or b-hCG elevation is frequently the first evidence of germ cell tumor recurrence; a confirmed elevation should prompt reinstitution of therapy ${ }^{23}$. 
The b-hCG level is used to diagnose gestational trophoblastic disease, a rare neoplastic complication of pregnancy. The b-hCG value is followed to assess response to treatment and to detect relapse in a manner similar to that for germ cell tumors ${ }^{24}$ (Table II).

\section{Cancer Antigen 125}

CA 125 is a glycoprotein normally expressed in coelomic epithelium during fetal development. This epithelium lines body cavities and envelopes the ovaries.

Elevated CA 125 values most often are associated with epithelial ovarian cancer, although levels also can be increased in other malignancies ${ }^{9}$. CA 125 levels are elevated in about 85 percent of women with ovarian cancer, but in only 50 percent of those with stage I disease. Higher levels are associated with increasing bulk of disease and are highest in tumors with nonmucinous histology ${ }^{9}$. Multiple benign disorders also are associated with CA 125 elevations, presumably by stimulation of the serosal surfaces(Table 1) 1-14 $^{1}$.

Insensitivity in early-stage disease and low disease prevalence limit the usefulness of CA 125 in ovarian cancer screening. In the largest study to date ${ }^{25}$, CA 125 levels were monitored in all patients annually for three years, and elevated values prompted ultrasound examinations. The positive predictive value was 20 percent, translating to five exploratory laparotomies for each ovarian cancer diagnosed. Survival was not improved in the women who were found through CA 125 screening to have ovarian cancer.

Randomized trials are being conducted to assess the role of CA 125 in ovarian cancer screening. Annual ultrasound examination and CA 125 screening have been advocated for women with hereditary ovarian cancer syndromes ${ }^{26}$.

CA 125 has been used as an adjunct in the diagnosis of pelvic masses. In postmenopausal women with asymptomatic palpable pelvic masses, CA 125 levels higher than 65 units per $\mathrm{mL}$ have a positive predictive value of 98 percent for ovarian cancer. Because premenopausal women have more benign causes of elevated CA 125 levels, testing for the marker is less useful in this population ${ }^{27}$.

Currently, ovarian cancer is treated with maximal surgical reduction, which leaves minimal clinical or radiographic disease ${ }^{26}$. Because studies have demonstrated concordance of CA 125 levels with disease activity, oncologists rely on CA 125 levels to guide therapeutic decisions ${ }^{28}$. After definitive treatment of ovarian cancer, CA 125 levels should be obtained every three months for two years, and with decreasing frequency thereafter. Elevated CA 125 levels during follow-up nearly always indicate ovarian cancer recurrence ${ }^{26 .}$

\section{Prostate-Specific Antigen(PSA)}

Prostate-specific antigen is a glycoprotein produced by prostatic epithelium. The PSA level can be elevated in prostate cancer, prostatitis, benign prostatic hypertrophy, and prostatic trauma, as well as after ejaculation(Table 1) ${ }^{1-14}$.

In men with prostatitis, PSA levels return to normal within eight weeks of symptom resolution. Waiting 48 hours after ejaculation to measure the PSA level has been recommended $^{13}$. Digital rectal examination does not elevate PSA levels above normal values ${ }^{29}$. In men who have been taking finasteride (Proscar) for more than six months, reported PSA levels should be doubled to accurately reflect true values, because the drug is an enzyme inhibitor that suppresses normal production of PSA by the prostate gland ${ }^{30}$.

In prostate cancer, the positive predictive value of PSA levels greater than $4 \mathrm{ng}$ per $\mathrm{mL}$ is 20 to 30 percent and rises to 50 percent when PSA levels exceed $10 \mathrm{ng}$ per $\mathrm{mL}$. Nevertheless, 20 to 30 percent of men with prostate cancer have PSA levels within normal ranges ${ }^{12}$.

Modifications to improve the positive predictive value of PSA testing include revised limits of normal based on age, race, velocity, density, and percentage of unbound (free) antigen. To date, these modifications have not resulted in improved outcomes. However, in patients with 
PSA values between 4 and $10 \mathrm{ng}$ per $\mathrm{mL}$, the PSA velocity and percentage of free PSA have been helpful in making clinical decisions. A velocity of $0.75 \mathrm{ng}$ per $\mathrm{mL}$ per year is predictive of cancer $^{31}$. When less than 10 percent of PSA is unbound, the positive predictive value for prostate cancer is 55 percent, compared with 8 percent when more than 25 percent of PSA is unbound ${ }^{32}$.

Prostate cancer screening remains controversial. Surrogate evidence of screening benefits include lower
PSA levels ${ }^{33}$ and earlier stage of disease at the time of initial diagnosis ${ }^{34}$. Limitations of screening include uncertainty about outcome benefit after treatment of localized prostate cancer ${ }^{35}$ potential identification of clinically insignificant tumors ${ }^{36}$ and attendant morbidity of treatment ${ }^{35}$. Experts from the American Urological Association suggest that patients should be given sufficient information to allow them to make an informed decision about prostate cancer screening using PSA levels (Table III) ${ }^{37}$.

\begin{tabular}{|l|}
\hline Table Ill. Information for patients about prostate cancer screening \\
\hline - Prostate cancer is common and potentially lethal; however, more patients die with, rather than from, the disease \\
\hline - Screening detects more cases of organ-confined disease, but there is no proof that this detection saves lives. \\
\hline - In most instances, prostate cancer is not the cause of an elevated PSA level. \\
\hline - Localized treatment of prostate cancer is effective but is associated with complications than can include impotence and incontinence. \\
\hline $\begin{array}{l}\text { - It is likely that prostate cancer screening using the PSA level is beneficial in a subset of men; however, the characteristics of this } \\
\text { subset have not been defined. }\end{array}$ \\
\hline PSA = Prostate-specific antigen \\
\hline
\end{tabular}

If PSA testing is undertaken, an age of 40 years has been suggested for initiation of screening in black men and in all men with a family history of prostate cancer. ${ }^{37}$ In patients without established risk factors and a minimum life expectancy of 10 years, screening could begin at age 50 . If elevated PSA values are confirmed, patients should be referred for biopsy. ${ }^{12}$ Randomized clinical trials are being conducted to assess the validity of these recommendations.

PSA levels predict the presence of metastatic disease. Patients with newly diagnosed prostate cancer and PSA levels below $20 \mathrm{ng}$ per $\mathrm{mL}$ rarely have osseous metastasis and do not need bone scanning, because the incidence of metastatic disease in these men is lower than 2 percent $^{38}$. In addition, computed tomographic scanning is unnecessary in men with PSA levels below $25 \mathrm{ng}$ per $\mathrm{mL}^{12}$. At our institution, if a prostate nodule is detected, the bone scan is widely positive, and the PSA level exceeds $100 \mathrm{ng}$ per $\mathrm{mL}$, treatment is often instituted without performance of biopsy.

After treatment of prostate cancer, PSA levels should be obtained every six months for five years, and then annually ${ }^{39}$. In men who have undergone radical prostatectomy, any detectable PSA is significant. ${ }^{12}$ Salvage radiotherapy may be appropriate in these patients if recurrence is limited to the prostate bed as determined by ProstaScint scanning, a nuclear medicine test using a radiolabeled antibody that targets only prostate tissue.

After radiotherapy, a PSA nadir is not reached for one to two years. Three consecutive elevations of the PSA level indicate biochemical relapse in previously irradiated patients. $^{12}$ Metastases do not become clinically evident for an average of eight years, and death does not occur for an average of 13 years. Thus, management decisions must include consideration of a patient's age and comorbid conditions ${ }^{40}$. 


\section{Cancer of Unknown Primary}

Confusion exists about the value of tumor markers in a patient with cancer of unknown primary. Intuitively, a panel of tumor markers should help to establish the origin of the tumor. Unfortunately, most tumor markers are too nonspecific for this purpose. However, with adenocarcinoma in older men, significant PSA elevations have sufficient specificity to make the diagnosis of prostate cancer.
In poorly differentiated tumors, AFP and b-hCG levels should be ordered. Marked elevations of these tumor markers signify the presence of an extragonadal germ cell tumor. In women with peritoneal carcinomatosis or malignant ascites, treatment for ovarian cancer is instituted if the CA 125 level is elevated. ${ }^{41}$

Tumor markers in common use are summarized in Table $^{4.1,5,8,12,16,24,26,27,39-41}$.

\begin{tabular}{|c|c|c|c|c|c|}
\hline \multicolumn{6}{|c|}{ Use of Tumour Marker } \\
\hline $\begin{array}{l}\text { Tumour } \\
\text { marker }\end{array}$ & Primary tumour(s) & Screening & Diagnosis & Follow-up after primary treatment & $\begin{array}{l}\text { Monitoring } \\
\text { treatment response }\end{array}$ \\
\hline CA $27.29^{1}$ & Breast cancer & No & No & $\begin{array}{l}\text { Consider in patients at high risk of } \\
\text { recurrence; obtain CA } 27.29 \text { level } \\
\text { every } 4 \text { to } 6 \text { months. }\end{array}$ & Helpful \\
\hline $\mathrm{CEA}^{16}$ & Colorectal cancer & No & No & $\begin{array}{l}\text { In patients at high risk of recurrence, } \\
\text { obtain CEA level every } 2 \text { to } 3 \\
\text { months for at least } 2 \text { years }\end{array}$ & Very helpful \\
\hline CA $19-9^{5}$ & $\begin{array}{l}\text { Pancreatic cancer, No } \\
\text { biliary tract cancer }\end{array}$ & No & $\begin{array}{l}\text { Selected pancreatic } \\
\text { masses }\end{array}$ & No & Helpful \\
\hline $\mathrm{AFP}^{8,20,41}$ & $\begin{array}{l}\text { Hepatocellular } \\
\text { carcinoma, } \\
\text { nonseminomatous germ } \\
\text { cell tumours, }\end{array}$ & $\mathrm{No}^{*}$ & $\begin{array}{l}\text { Poorly differentiated } \\
\text { cancer of unknown } \\
\text { primary; patients with } \\
\text { cirrhosis and liver } \\
\text { mass }\end{array}$ & $\begin{array}{l}\text { In patients treated for } \\
\text { nonseminomatous germ cell tumour, } \\
\text { obtain AFP and b-h CG levels every } \\
1 \text { to } 2 \text { months for } 1 \text { year, then } \\
\text { quarterly for } 1 \text { year and less } \\
\text { frequently thereafter. }\end{array}$ & $\begin{array}{l}\text { Essential in patients } \\
\text { treated for } \\
\text { nonseminomatous } \\
\text { germ cell tumours, } \\
\text { very helpful in } \\
\text { patients treated for } \\
\text { hepatocellular } \\
\text { carcinoma. }\end{array}$ \\
\hline b-h CG C $^{8,24,41}$ & $\begin{array}{l}\text { Nonseminomatous germ } \\
\text { cell tumour, gestational } \\
\text { trophoblastic disease }\end{array}$ & No & $\begin{array}{l}\text { Poorly differentiated } \\
\text { cancer of unknown } \\
\text { primary; gestational } \\
\text { trophoblastic disease }\end{array}$ & $\begin{array}{l}\text { Nonseminomatous germ cell } \\
\text { tumour: see AFP above. In patients } \\
\text { treated for gestational trophoblastic } \\
\text { disease, obtain b-h CG level once a } \\
\text { month for } 6 \text { to } 12 \text { months. }\end{array}$ & $\begin{array}{l}\text { Essential in patients } \\
\text { treated for } \\
\text { nonseminomatous } \\
\text { germ cell tumour or } \\
\text { gestational } \\
\text { trophoblastic disease }\end{array}$ \\
\hline CA $125^{26,27,41}$ & Ovarian cancer & $\mathrm{No}^{* *}$ & $\begin{array}{l}\text { Adjunct for diagnosis } \\
\text { of pelvic mass in } \\
\text { postmenopausal } \\
\text { women; malignant } \\
\text { ascites in women with } \\
\text { cancer of unknown } \\
\text { primary }\end{array}$ & $\begin{array}{l}\text { Obtain CA } 125 \text { level every } 3 \text { months } \\
\text { for } 2 \text { years, then less frequently. }\end{array}$ & Very helpful \\
\hline
\end{tabular}




\begin{tabular}{|l|l|c|c|l|}
\hline PSA $^{12,39,41}$ & Prostate cancer & $\begin{array}{c}\text { Adenocarcinoma of } \\
\text { unknown primary; } \\
\text { widely positive bone } \\
\text { scan and prostate } \\
\text { mass. }\end{array}$ & $\begin{array}{l}\text { Obtain PSA level every } 6 \text { months for } \\
5 \text { years, then annually }{ }^{39} . \text { Any } \\
\text { detectable Psa after redical } \\
\text { prostatectomy indicated recurrence. } \\
\text { Three consecutive PSA elevations } \\
\text { after radiation therapy indicate } \\
\text { recurrence. }\end{array}$ & Very helpful \\
\hline
\end{tabular}

in the 1990s. South Med J 1997;90:972-81.

10. Chen DX, Schwartz PE, Li XG, Yang Z. Evaluation of CA 125 levels in differentiating malignant from benign

\section{REFERENCES}

1. Chan DW, Beveridge RA, Muss $H$, Fritsche $H A$, Hortobagyi $G$, Theriault $R$, et al. Use of Truquant BR radioimmunoassay for early detection of breast cancer recurrence in patients with stage II and stage III disease. J Clin Oncol 2004;15:2322-8.

2. Gion M, Mione R, Leon AE, Dittadi R. Comparison of the diagnostic accuracy of CA27.29 and CA15.3 in primary breast cancer. Clin Chem 2003;45:630-7.

3. Fletcher RH. Carcinoembryonic antigen. Ann Intern Med 1996; 104:66-73. Clinical practice guidelines for the use of tumor markers in breast and colorectal cancer. Adopted on May 17, 1996, by the American Society of Clinical Oncology. J Clin Oncol 1996;14:2843-77.

4. Steinberg W. The clinical utility of the CA 19-9 tumorassociated antigen. Am J Gastroenterol 1990;85:350-5.

5. Johnson PJ. The role of serum alpha-fetoprotein estimation in the diagnosis and management of hepatocellular carcinoma. Clin Liver Dis 2001;5:145-59.

6. Fowler JE Jr, Platoff GE, Kubrock CA, Stutzman RE. Commercial radioimmunoassay for beta subunit of human chorionic gonadotropin: falsely positive determinations due to elevated serum luteinizing hormone. Cancer 1982;49:136-9.

7. Bosl GJ, Bajorin DF, Sheinfeld J, Motzer RJ, Chaganti RS. Cancer of the testis. In: DeVita VT, Hellman S, Rosenberg $\mathrm{SA}$, et al., eds. Cancer, principles and practice of oncology. 6th ed. Philadelphia: Lippincott, Williams \& Wilkins, 2001:1491-518.

8. Tuxen MK, Soletormos G, Dombernowsky P. Tumor markers in the management of patients with ovarian cancer. Cancer Treat Rev 1995;21:215-45.

9. Gallup DG, Talledo E. Management of the adnexal mass

14. Ballesta AM, Molina R, Filella X, Jo J, Gimenez N. Carcinoembryonic antigen in staging and follow-up of patients with solid tumors. Tumour Biol 1995;16:32-41.

Bast RC Jr, Ravdin P, Hayes DF, Bates S, Fritsche H Jr, Jessup JM, et al. 2000 update of recommendations for the use of tumor markers in breast and colorectal cancer: clinical practice guidelines of the American Society of Clinical Oncology. J Clin Oncol 2001;19:1865-78.

Bruinvels DJ, Stiggelbout AM, Kievit J, van Houwelingen HC, Habbema JD, van de Velde CJ. Follow-up of patients with colorectal cancer. A meta-analysis. Ann Surg 1994;219:174-82.

Kim HJ, Kim MH, Myung SJ, Lim BC, Park ET, Yoo KS, et al. A new strategy for the application of CA19-9 in the differentiation of pancreaticobiliary cancer: analysis using a receiver operating characteristic curve. Am J Gastroenterol 1999;94:1941-6. 

Subclinical hepatocellular carcinoma: an analysis of 391 patients. J Surg Oncol Suppl 1993;3:55-8.

Yuen MF, Cheng CC, Lauder IJ, Lam SK, Ooi CG, Lai CL. Early detection of hepatocellular carcinoma increases the chance of treatment: Hong Kong experience. Hepatology 2000;31:330-5.

International Germ Cell Consensus Classification: a prognostic factor-based staging system for metastatic germ cell cancers. International Germ Cell Cancer Collaborative Group. J Clin Oncol 1997;15:594-603.

Mazumdar M, Bajorin DF, Bacik J, Higgins G, Motzer RJ, Bosl GJ. Predicting outcome to chemotherapy in patients with germ cell tumors: the value of the rate of decline of human chorionic gonadotropin and alphafetoprotein during therapy. J Clin Oncol 2001;19:253441.

Einhorn LH. Treatment of testicular cancer: a new and improved model. J Clin Oncol 1990;8:1777-81.

Diseases and abnormalities of the placenta. In: Cunningham FG, et al., eds. Williams Obstetrics. 21st ed. New York: McGraw-Hill, 2001:835-47.

Jacobs IJ, Skates SJ, MacDonald N, Menon U, Rosenthal AN, Davies AP, et al. Screening for ovarian cancer: a pilot randomised controlled trial. Lancet 1999;353:1207-10.

25. National Institutes of Health Consensus Development Conference Statement. Ovarian cancer: screening, treatment, and follow-up. Gynecol Oncol 1994;55(3 pt 2):S4-14.

26. Malkasian GD Jr, Knapp RC, Lavin PT, Zurawski VR Jr, Podratz KC, Stanhope CR, et al. Preoperative evaluation of serum CA 125 levels in premenopausal and postmenopausal patients with pelvic masses: discrimination of benign from malignant disease. Am J Obstet Gynecol 1988;159:341-6.

27. Bridgewater JA, Nelstrop AE, Rustin GJ, Gore ME, McGuire WP, Hoskins WJ. Comparison of standard and CA-125 response criteria in patients with epithelial ovarian cancer treated with platinum or paclitaxel. J Clin Oncol 1999;17:501-8.

28. Crawford ED, Schutz MJ, Clejan S, Drago J, Resnick MI, Chodak GW, et al. The effect of digital rectal examination on prostate-specific antigen levels. JAMA 1992;267:2227-8.

29. Guess HA, Gormley GJ, Stoner E, Oesterling JE. The effect of finasteride on prostate specific antigen: review of available data. J Urol 1996;155:3-9.

30. Carter HB, Pearson JD, Metter EJ, Brant LJ, Chan DW, Andres $R$, et al. Longitudinal evaluation of prostate. specific antigen levels in men with and without prostate disease. JAMA 1992;267:2215-20.

31. Catalona WJ, Partin AW, Slawin KM, Brawer MK, Flanigan $R C$, Patel $A$, et al. Use of the percentage of free prostate-specific antigen to enhance differentiation of prostate cancer from benign prostatic disease: a prospective multicenter clinical trial. JAMA 1998;279:1542-7.

32. Partin AW, Kattan MW, Subong EN, Walsh PC, Wojno KJ, Oesterling JE, et al. Combination of prostate-specific antigen, clinical stage, and Gleason score to predict pathological stage of localized prostate cancer. A multi-institutional update. JAMA 1997;277: 1445-51.

33. Catalona WJ, Smith DS, Ratliff TL, Basler JW. Detection of organ-confined prostate cancer is increased through prostate-specific antigen-based screening. JAMA 1993;270:948-54.

34. Harris R, Lohr KN. Screening for prostate cancer: an update of the evidence for the U.S. Preventive Services Task Force. Ann Intern Med 2002;137:917-29

35. Albertsen PC. The role of PSA screening in early detection of prostate cancer. PPO Updates 2001;15:1. 16.

36. Burack RC, Wood DP Jr. Screening for prostate cancer. The challenge of promoting informed decision making in the absence of definitive evidence of effectiveness Med Clin North Am 1999;83:1423-42, vi.

37. Oesterling JE, Martin SK, Bergstralh EJ, Lowe FC. The use of prostate-specific antigen in staging patients with newly diagnosed prostate cancer. JAMA 1993;269:57-60.

38. Millikan R, Logothetis C. Update of the NCCN guidelines for treatment of prostate cancer. Oncology [Huntingt] 1997;11(11A): 180-93.

40. Pound CR, Partin AW, Eisenberger MA, Chan DW, 
Pearson JD, Walsh PC. Natural history of progression after PSA elevation following radical prostatectomy. JAMA 1999;281:1591-7.

41. Greco FA, Hainsworth JD. Cancer of unknown primary site. In: DeVita VT Jr, Hellman S, Rosenberg SA, et al. eds. Cancer, principles and practice of oncology. 6 th ed. Philadelphia: Lippincott Williams \& Wilkins, 2001:2537-60. 